Copyright by the American Society of Agricultural and Biological Engineers. Cho, J.; Mostaghimi, S.; Kang, M. S.; Chun, J. A., "Sensitivity to grid and time resolution of hydrology components of DANSAT," Transactions of the ASABE. 52(4): 1121-1128. (doi: 10.13031/2013.27789) @2009

\title{
SENSITIVITY TO GRID AND TIME RESOLUTION of Hydrology COMPONENTS OF DANSAT
}

\author{
J. Cho, S. Mostaghimi, M. S. Kang, J. A. Chun
}

\begin{abstract}
A sensitivity analysis of the Dynamic Agricultural Nonpoint Source Assessment Tool (DANSAT) model to different grid sizes and time steps was conducted to investigate scale effects on hydrology and to provide users with a guideline for selecting an appropriate grid size and time step in order to enhance computational time efficiency. Response of the hydrology components to different grid sizes was analyzed by considering: (1) changes in input parameter values due to GIS manipulation processes, and (2) comprehensive response of the model through applications to a small agricultural subwatershed (QN2) in the Nomini Creek watershed, Virginia. In addition, model response to different time steps was analyzed in QN2 by changing the storm event time step (SET) of the model (1, 5, 10, 15, 30, 45, and 60 min) against a fixed grid size. A maximum acceptable grid size (MAG) of $90 \mathrm{~m}$ was selected for QN2, considering changes in the accuracy of spatial data for different grid sizes. Only the overall response of the hydrology components to down-scaled $(60 \mathrm{~m})$ grid size in QN2 was acceptable without any further calibration. Daily streamflow for storm events decreased with increases in time step from 1 to $60 \mathrm{~min}$, while total runoff for the simulation period increased slightly by $8 \%$. Use of MAG $(90 \mathrm{~m})$ with an acceptable larger time step $(10 \mathrm{~min})$ based on monthly runoff criteria exponentially reduced computational time compared to an application using the smallest grid size and time step. Site-specific sensitivity analysis is recommended due to the possible differences in response of the hydrology components to watersheds with different hydrologic characteristics.
\end{abstract}

Keywords. Best management practices, DANSAT, Grid size, Nonpoint-source pollution, Sensitivity, Time step.

$\mathrm{D}$ istributed and physically based nonpoint-source (NPS) pollution models are appropriate for simulating the effectiveness of best management practices (BMPs) and have been used in evaluating the impacts of BMPs on hydrology and water quality (Bouraoui and Dillaha, 1996). Several limitations, including requirements for intensive input parameters and computational time, restrict application of physically based distributed models. Parameters of distributed models can be divided into two categories: functional and structural (Xevi et al., 1997). Structural parameters, which should be selected before the preparation of functional parameters for the distributed modeling application, include grid size and time step.

Grid size has been determined to be arbitrary in most NPS modeling, based on manpower, database resolution and storage, and time constraints. More appropriately, selection of grid size should be based on the spatial variability of the wa-

Submitted for review in April 2008 as manuscript number SW 7468; approved for publication by the Soil \& Water Division of ASABE in July 2009.

The authors are Jaepil Cho, ASABE Member, Research Associate, USDA-ARS Northwest Watershed Research Center, Boise, Idaho; Saied Mostaghimi, ASABE Fellow, H. E. and Elizabeth F. Alphin Professor and Head, Department of Biological Systems Engineering, Virginia Tech, Blacksburg, Virginia; Moon Seong Kang, Assistant Professor, Department of Rural Systems Engineering, Research Institute for Agriculture and Life Sciences, Seoul National University, Seoul, Korea; and Jong Ahn Chun, ASABE Member, Research Agricultural Engineer, USDA-ARS Crop Systems and Global Change Laboratory, Beltsville, Maryland. Corresponding author: Jong Ahn Chun, USDA-ARS Crop Systems and Global Change Laboratory, 10300 Baltimore Ave, Bldg 001, Rm 301, Beltsville, MD 20705; phone: 301-504-6633; fax: 301-504-5823; e-mail: jongahn.chun@ars.usda.gov. tershed and the computational algorithm of the model (Vieux and Needham, 1993). Dillaha (1990) recommended a smaller grid size for distributed parameter models in order to satisfy the assumption that all properties, including soil and land use, are homogeneous within each grid. However, reduction of grid size tremendously increases computational time and the time needed for data collecting and processing (Vazquez et al., 2002). Previous studies have focused only on the effects of different grid sizes, especially digital elevation model (DEM), on the parameterization and representation of watershed characteristics (Armstrong and Martz, 2003; Moglen and Hartman, 2001). More attention has been paid to grid size sensitivity analysis of specific models such as TOPMODEL (Brasington and Richards, 1998; Saulnier et al., 1997; Valeo and Moin, 2000; Kuo et al., 1999), CASC2D (Molnar and Julien, 2000), AGNPS (Panuska et al., 1991; Vieux and Needham, 1993), ANSWERS (Brown et al., 1993), and MIKE SHE (Refsgaard, 1997; Vazquez et al., 2002). However, selecting the appropriate grid resolution for a particular hydrologic model is limited by difficulties in separating errors associated with: (1) scale effects on land surface representation, and (2) the concept and assumptions upon which the computational algorithms of a particular model are based (Vazquez et al., 2002).

Distributed and physically based models usually use a short time step compared to semi-lumped and conceptual models such as HSPF (Bicknell et al., 1993) and SWAT (Arnold et al., 1998). The choice of a short time step in physically based distributed models along with larger number of cells for representing the watershed increases the computational time. Borah and Bera (2003) summarized the temporal scale of existing distributed NPS pollution models. AnnAGNPS (Bingner and Theurer, 2001) uses a daily time step; the cur- 
rent version of ANSWERS-2000 (Bouraoui and Dillaha, 1996) uses dual time steps (daily for dry days and $30 \mathrm{~s}$ for days with precipitation); and MIKE SHE and CASC2D use variable steps depending on numerical stability. It has also been noted that CASC2D and MIKE SHE would be appropriate for application to small watersheds in continuous simulation mode due to their computationally intensive numerical scheme (Borah and Bera, 2003).

The Dynamic Agricultural Nonpoint Source Assessment Tool (DANSAT) is a newly developed physically based distributed NPS model (Cho, 2007; Cho and Mostaghimi, 2009a, 2009b, 2009c). The user can choose different grid sizes and time steps based on available data, purpose of the modeling, and acceptable computational time. DANSAT also has a practical limitation when applied to a watershed with a large number of cells due to the intensive required computational time stemming from its physically based and distributed model characteristics. Selection of a coarser grid size or a larger time step is attractive for a watershed-scale simulation of DANSAT because it would substantially reduce computational time. Thus, it is necessary to provide users with a guideline for selecting the appropriate grid size and time step for this model.

The overall goal of this study was to analyze the structural sensitivities of the hydrology components of DANSAT to provide appropriate ranges of grid size and time step so as to decrease computational time without a significant decrease in modeling accuracy. Specific objectives were: (1) to analyze the impacts of different grid sizes on representation of watershed characteristics and hydrology, and (2) to analyze the response of the hydrology components to different time steps.

\section{Materials ANd Methods DANSAT}

DANSAT is a distributed and physically based model for simulating long-term impacts of agricultural BMPs on hydrology, sediment, and pesticides at watershed scale. DANSAT consists of both cell-scale and watershed-scale components. The cell-scale components, including interception, infiltration, percolation, and evapotranspiration, are used to simulate water movement in one cell. Interception is estimated as a function of the aboveground biomass of vegetation using the equation from the Water Erosion Prediction Project (WEPP) (Savabi and Williams, 1995). DANSAT separately calculates actual soil evaporation and plant transpiration using the Ritchie methods (Ritchie, 1972) based on calculated potential evapotranspiration with the PriestlyTaylor method (Priestley and Taylor, 1972). Then DANSAT distributes calculated soil evaporation into multiple soil layers within the maximum soil evaporation effective depth that is estimated based on soil texture (Savabi and Williams, 1995) while calculated plant transpiration is distributed within the root depth that is predicted based on the process developed by Borg and Grimes (1986). Available soil water is extracted starting from the first soil layer to the maximum depth until the sum of extracted water is equal to the calculated soil evaporation or plant transpiration. The modified Green-Ampt model by Chu (1978) was selected because of its physically based characteristics and ease in its parameter estimation of the Green-Ampt approach (Green and Ampt,
1911). The capacity-based percolation approach (Savabi and Williams, 1995) was adapted in DANSAT by considering: (1) the adjusted hydraulic conductivity that varies depending on soil water content, and (2) the effect of lower-layer water content that may restrict water movement through a soil layer at or near saturation. The remaining water in excess of the field capacity of each soil layer is percolated down to the next soil layer until the percolated water reaches the groundwater.

Watershed-scale components, including interflow, baseflow, overland flow, and channel flow components, route the water to downslope cells until reaching the watershed outlet. Watershed-scale hydrology components can be significantly influenced by changes in grid size because water calculated by the cell-scale components in each cell is routed to downslope cells using watershed-scale components until the watershed outlet is reached. A concept of the kinematic storage model, which was developed by Sloan et al. (1983) and used in SWAT (Neitsch et al., 2002), was used for subsurface lateral flow routing based on the lumped interflow pool approach. In the lumped interflow approach, soil water exceeding the field capacity of each soil layer is lumped into the interflow pool, and interflow to adjacent cells is calculated based on the depth of water in the pool. Groundwater flow from each overland cell to the nearest stream segment is calculated based on a similar concept used in SWAT (Neitsch et al., 2002). Total base flow inflow to the stream segment is the summation of individual base flows from the nearest overland cells as a function of saturated hydraulic conductivity and distance from the current overland cell to the nearest stream cell. Overland flow routing is computed based on storage-based equations that consist of the spatially uniform and temporarily variable continuity equation and Manning's equation. The discrete form of the continuity equation is changed to a simple equation containing only one unknown variable, flow depth at the end of the time step, by plugging Manning's equation into the continuity equation. The variable storage routing method by Williams (1969) was selected for channel flow routing. Detail information on selected equations and a flowchart of hydrology components of DANSAT are provided by Cho and Mostaghimi (2009b).

DANSAT uses four different time steps, including surface water time step (SWT), storm event time step (SET), before rainfall time step (BRT), and after runoff time step (ART) (Cho and Mostaghimi, 2009b). The default SWT is defined as one day and is used for simulation of evapotranspiration regardless of rainfall and percolation in a non-rainfall day. If there is a rainfall event, then SWT is divided into three different time steps: BRT, SET, and ART. Only SET can be changed as user input, while BRT and ART are internally decided by DANSAT depending on the starting time of rainfall (from beginning of the day to starting time of rainfall) and the ending time of runoff (from ending time of runoff to the end of the day), respectively. Storm-related components such as interception, infiltration, and routing-related components are simulated using the SET.

\section{Nomini Creek WATershed}

The QN2 subwatershed (214 ha) within the Nomini Creek (NC) watershed (Inamdar et al., 2001), which was used for evaluating capability of DANSAT in predicting impacts of temporal variations and spatial distribution of agricultural land management on hydrology and sediment (Cho and Mostaghimi, 2009a), was selected for this study. The Nomini 


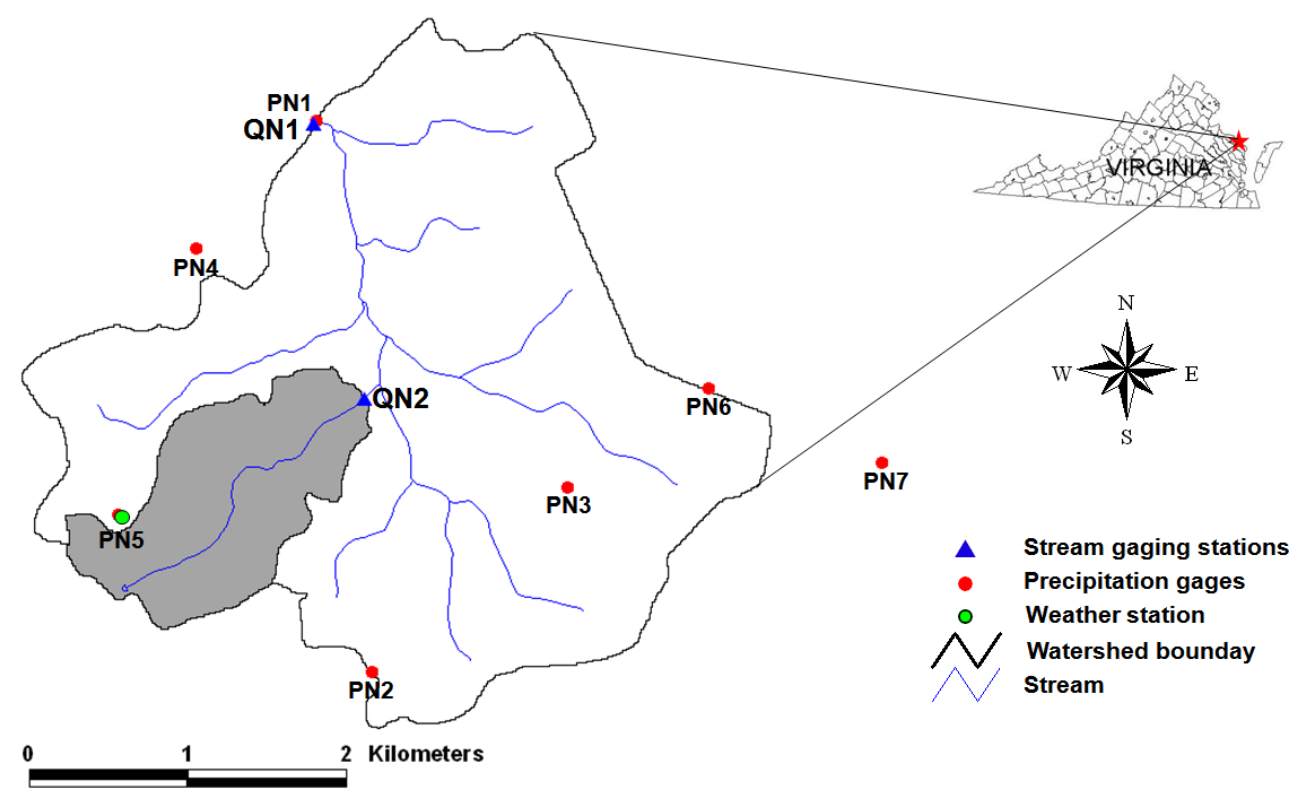

Figure 1. Location and monitoring network of Nomini Creek watershed.

Creek watershed is located in Westmoreland County within the Coastal Plain region of Virginia (fig. 1). Surface hydrology and water quality were monitored from 1986 to 1996 (Mostaghimi et al., 1989). Seven precipitation monitoring stations (PN1 through PN7) were installed to characterize the spatial distribution of rainfall. Additional meteorological data including evaporation, wind direction and speed, air temperature, and relative humidity were measured at station PN5. Land use in the NC watershed is mainly agricultural, with $49 \%$ cropland, $47 \%$ woodland, and $4 \%$ residential and roads. Corn, soybeans, and small grains are the major crops grown in the watershed. Actual land use changes were recorded during the project period in a series of field boundary maps and attribute files in a digital format. Suffolk soil, which is characterized by a sandy loam texture, covers $58 \%$ of the watershed. The Rumford series, which is classified as sandy loam, covers approximately $33 \%$ of the watershed. Both soils are deep and well drained. The elevation of QN2 varies from approximately $15.7 \mathrm{~m}$ near the subwatershed outlet to $52.4 \mathrm{~m}$ in the southwest part of the subwatershed. The influence of baseflow on total runoff at the subwatershed outlet is significant because of high groundwater tables. Additional information regarding the procedures for data collection and data analysis are given by Mostaghimi et al. (1989).

Procedures for preparing meteorological, topographic, soil, and land use input data and estimating parameters for calibration are described by Cho and Mostaghimi (2009a). The same structural and functional parameters from the previous study by Cho and Mostaghimi (2009a) were used for deriving baseline simulation results for the grid size and time step sensitivity analysis. Storm event time step was fixed at a minimum value of $1 \mathrm{~min}$, and the subwatershed area was divided into a total of 265 uniform cells, each 0.81 ha $(90 \times$ $90 \mathrm{~m}$ ) in size. Watershed-scale parameters, which affect the overall watershed and contain higher uncertainty, were used for the calibration process instead of using spatially distributed topographic and soil related parameters (Cho and Mostaghimi, 2009a). These parameters included: effective soil depth for infiltration, rainfall adjustment factor for effective hydraulic conductivity, anisotropic factor for interflow calculation, and soil depth for interflow calculation. In addition, groundwater-related parameters were used for calibrating hydrology because a great portion of the total runoff at QN2 comes from baseflow. The selected parameter set was not changed during the grid size and time step sensitivity analyses.

Percent errors for both the calibration period (1987-1990) and the validation period (1991-1992) were smaller than $\pm 10 \%$, with $-0.64 \%$ and $-5.12 \%$, respectively. The hydrology components predicted the temporal fluctuations in stream flows reasonably well, although the base flow component of DANSAT had difficulties in simulating the fluctuations in base flow. The daily Nash-Sutcliffe efficiency index (NSE) (Nash and Sutcliffe, 1970) values were 0.59 and 0.66 for the calibration and validation periods, respectively. However, monthly NSE for the calibration period was 0.53 , while the corresponding value for the validation period was smaller than 0.5. Model performance in the QN2 subwatershed was highly influenced by the baseflow component that converts spatially and temporally assigned groundwater recharge to base flow at stream segments (Cho and Mostaghimi, 2009a). For the base line application, only the calibration period (1 January 1987 to 31 December 1990) was used. Figure 2 show daily time series and monthly scatter plots of observed and simulated flows for the calibration period.

\section{Grid Size Sensitivity Analysis}

Grid size sensitivity analysis was conducted in two steps. First, due to the fact that collection and manipulation of spatial data is the first step in a distributed watershed-scale model application, changes in representing accuracy of spatially distributed parameters at different grid sizes through the commonly used GIS manipulation processes were analyzed to select a maximum acceptable grid size (MAG) for further application. To analyze changes in topographic parameters during the watershed delineation process, the original $30 \mathrm{~m}$ DEM was aggregated successively to coarser grids of 60,90 , 


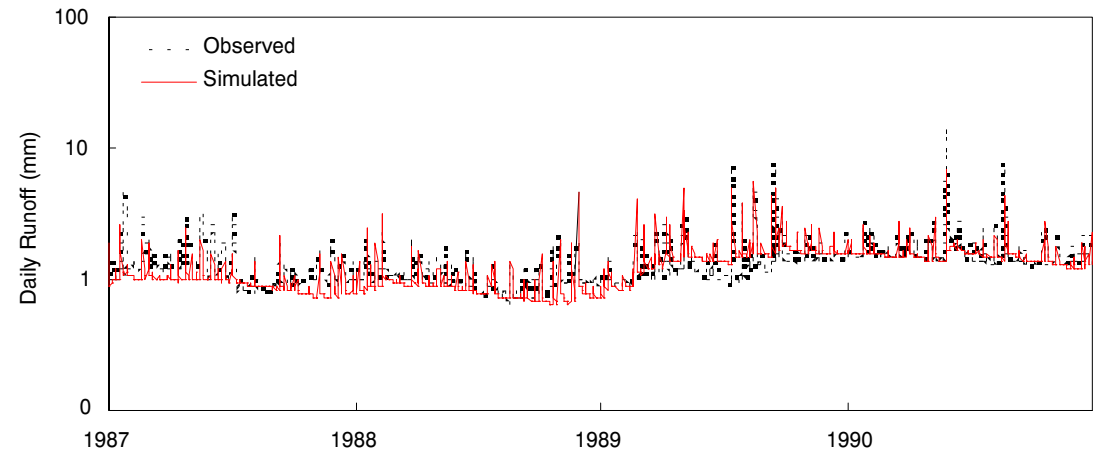

(a)

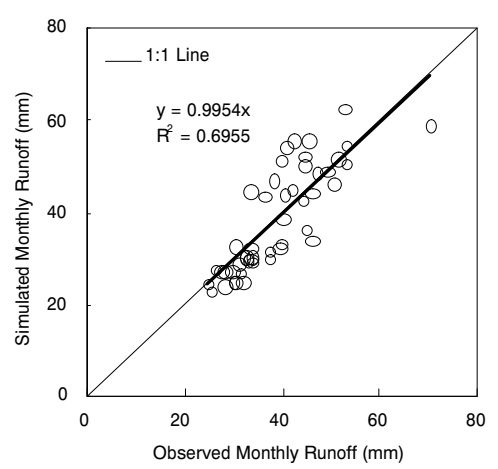

(b)

Figure 2. Comparison of observed and simulated flow for the calibration period: (a) time series for daily flow, and (b) scatter plots for monthly flow.

$120,150,180,210,240$, and $270 \mathrm{~m}$ resolutions using a bilinear interpolation method. Topographic parameters including watershed boundary, stream networks, and overland slope were derived based on each selected DEM resolution. Soil and land use data, which usually exist in vector format, were transformed into grid format using ArcView for the selected grid sizes. Delineated watershed boundary and rasterized soil and land use data for each grid size were re-sampled back to $30 \mathrm{~m}$ for calculating accuracy through cell-by-cell comparison. It was assumed that the spatial data derived using the finer grid size $(30 \mathrm{~m})$ was the most accurate and closest to actual watershed conditions. The concept of error matrix (Campbell, 2002), which is commonly used in image processing for the calculation of land use classification accuracy, was selected to calculate the error occurring during the GIS manipulation processes. Second, the overall response of DANSAT to the different grid sizes was analyzed for the QN2 subwatershed. Grid sizes were determined based on the MAG, which was determined during the GIS manipulation process, for considering both up-scale and down-scale impacts on hydrology. The time step was fixed as 1 min during the overall grid size sensitivity analysis.

\section{Time Step Sensitivity Analysis}

Different SETs of 1, 5, 10, 15, 30, 45, and 60 min were selected for the time step sensitivity analysis. Grid size was fixed as the MAG during the entire time step sensitivity analysis. For each selected time step, only breakpoint rainfall input data were replaced without changing any other input parameters.

\section{Results AND Discussion \\ Grid Size Sensitivity ANALYsis}

Table 1 shows the spatial accuracy of watershed boundary, soil, and land use for each grid size using spatial data at $30 \mathrm{~m}$ grid size as a reference. Variations in spatial distribution of watershed boundary, channel network, soil, and land use for various grid sizes are shown in figure 3. MAG was decided based on both visual comparison and quantitative criteria. With increased grid resolution, there is difficulty in representing spatial distribution of soil and land use types. Small polygons of soil and land use disappeared or were exaggerated as grid size increased because ArcView uses a centroid algorithm for the rasterization processes (ESRI, 1998). The algorithm chooses any polygon that exists at the center of each grid even though the polygon is not the dominant type within the grid. The spatial distributions of watershed boundary, soil types, and land use are represented with sufficient accuracy for any grid size smaller than $90 \mathrm{~m}$ (fig. 3). The MAG of $90 \mathrm{~m}$ was decided based on calculated accuracies of soil and land use grids using $80 \%$ accuracy as a minimum acceptable criterion (table 1).

Variations in elevation, overland slope, and depth to the groundwater table within the grid size range of $30 \mathrm{~m}$ to $120 \mathrm{~m}$ are shown in table 2 . The $120 \mathrm{~m}$ grid size was included so as to consider up-scale impacts during the analysis of overall response of the hydrology components to grid size. Overland slope is one of the sensitive topographic parameters directly used as input for overland flow routing, and depth to groundwater table is related to recharge by influencing the travel time of infiltrated water. Table 2 shows that the mean and maximum values of overland slope decreased as grid size increased. The changes in elevation and depth to the groundwater table were negligible.

Response of the hydrology components to different grid sizes for QN2 is summarized in table 3. Total runoff at the watershed outlet increased as grid size increased. Increase in grid size from MAG $(90 \mathrm{~m})$ to $120 \mathrm{~m}$ increased total runoff by $2 \%$, while decrease in grid size to $60 \mathrm{~m}$ decreased total runoff by $1 \%$. Spatially averaged total recharge also increased as grid size increased within the range of $60 \mathrm{~m}$ to $120 \mathrm{~m}$, with a minimum recharge of $644 \mathrm{~mm} / \mathrm{cell}$ at the $60 \mathrm{~m}$ grid size. A rapid increase (9\%) in spatially averaged total recharge occurred between the $90 \mathrm{~m}$ and $120 \mathrm{~m}$ grid sizes, compared to increases of $2 \%$ between the $60 \mathrm{~m}$ and $90 \mathrm{~m}$ grid sizes. Reductions in average surface slope according to increase in grid size (table 2) may increase infiltration, with a

Table 1. Watershed delineation and rasterization errors for each grid resolution.

\begin{tabular}{|c|c|c|c|c|c|c|}
\hline \multirow{2}{*}{$\begin{array}{l}\text { Grid } \\
\text { Size } \\
\text { (m) }\end{array}$} & \multicolumn{2}{|c|}{ Boundary } & \multicolumn{2}{|c|}{ Soil } & \multicolumn{2}{|c|}{ Land Use } \\
\hline & $\begin{array}{c}\text { Accuracy } \\
(\%)\end{array}$ & $\begin{array}{l}\text { Area } \\
\text { (ha) }\end{array}$ & $\begin{array}{c}\text { Accuracy } \\
(\%)\end{array}$ & $\begin{array}{l}\text { No of } \\
\text { Types }\end{array}$ & $\begin{array}{c}\text { Accuracy } \\
(\%)\end{array}$ & $\begin{array}{l}\text { No of } \\
\text { Types }\end{array}$ \\
\hline 30 & 100 & 210 & 100.0 & 7 & 100.0 & 53 \\
\hline 60 & 94.3 & 210 & 87.2 & 7 & 89.1 & 44 \\
\hline 90 & 90.5 & 215 & 80.2 & 7 & 83.0 & 43 \\
\hline 120 & 87.6 & 223 & 73.6 & 6 & 78.3 & 37 \\
\hline 150 & 84.4 & 207 & 67.6 & 6 & 73.7 & 31 \\
\hline 180 & 84.1 & 214 & 63.7 & 7 & 69.8 & 28 \\
\hline 210 & 80.7 & 212 & 62.8 & 5 & 70.3 & 20 \\
\hline 240 & 78.6 & 225 & 63.6 & 5 & 68.1 & 18 \\
\hline
\end{tabular}



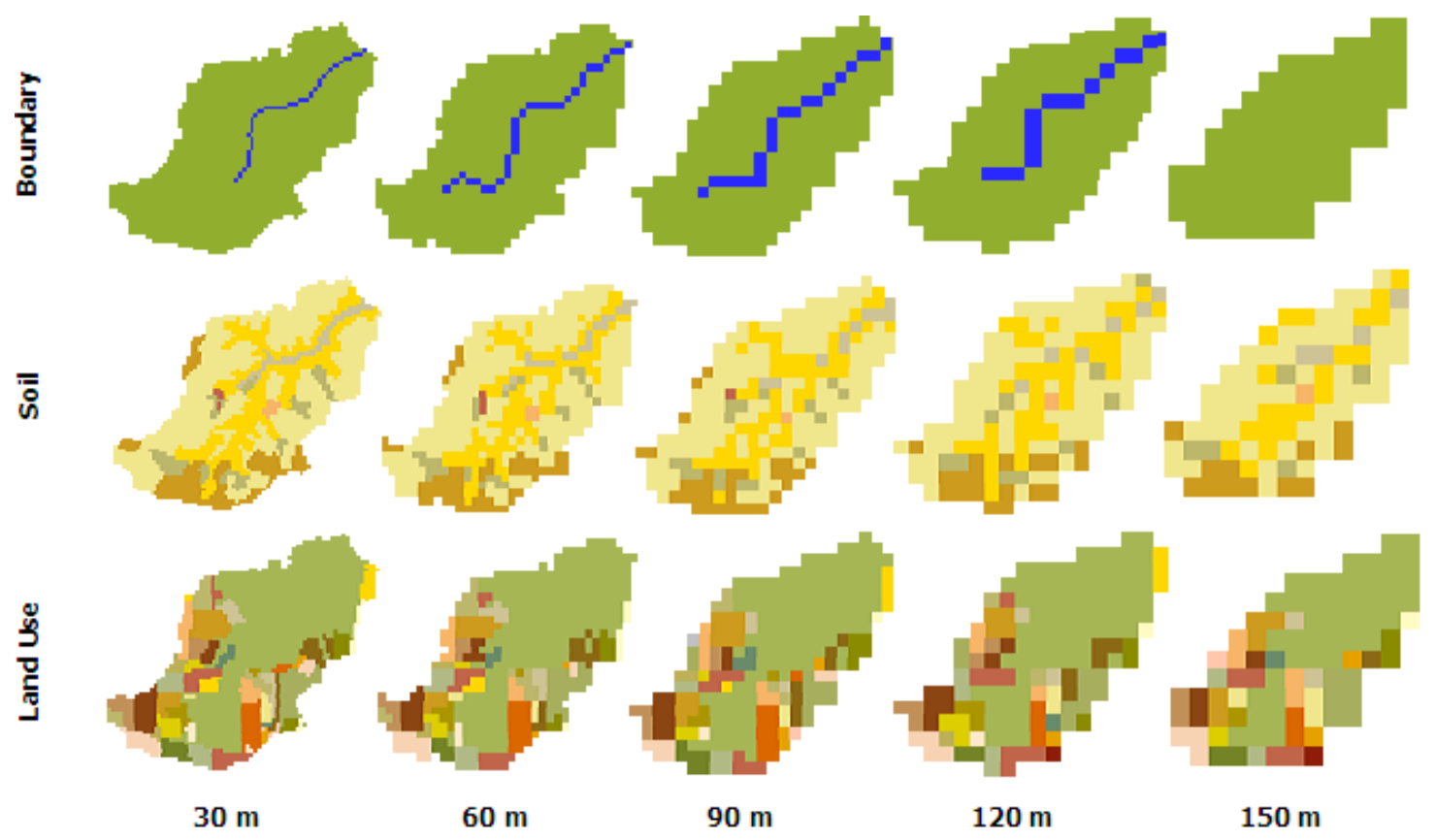

Figure 3. Variations in spatial distribution of watershed boundary and channel network, soil type, and land use for various grid resolutions.

consequent result of increase in groundwater recharge. However, variations in elevation, overland slope, and depth to groundwater table at various grid sizes, shown in table 2, were not enough to explain the rapid increase in recharge between the $90 \mathrm{~m}$ and $120 \mathrm{~m}$ grid sizes because the topographic parameters were linearly changed or were stable within the $60 \mathrm{~m}$ and $120 \mathrm{~m}$ grid sizes. The rapid increase in spatially averaged recharge values between $90 \mathrm{~m}$ and $120 \mathrm{~m}$ grid sizes
Table 2. Variation in elevation and slope for various grid sizes.

\begin{tabular}{|c|c|c|c|c|c|c|}
\hline \multirow{2}{*}{$\begin{array}{l}\text { Grid } \\
\text { Size } \\
\text { (m) }\end{array}$} & \multicolumn{2}{|c|}{$\begin{array}{l}\text { Elevation } \\
\text { (m) }\end{array}$} & \multicolumn{2}{|c|}{$\begin{array}{l}\text { Overland } \\
\text { Slope }(\%)\end{array}$} & \multicolumn{2}{|c|}{$\begin{array}{c}\text { Depth to GW } \\
\text { Table (m) }\end{array}$} \\
\hline & Mean & Max. & Mean & Max. & Mean & Max. \\
\hline 30 & 39.1 & 52.4 & 23.8 & 159.0 & 14.4 & 31.0 \\
\hline 60 & 38.8 & 52.4 & 19.4 & 86.0 & 14.1 & 30.5 \\
\hline 90 & 38.6 & 51.6 & 16.6 & 67.0 & 14.5 & 30.7 \\
\hline 120 & 38.8 & 52.1 & 13.8 & 47.0 & 14.5 & 30.5 \\
\hline
\end{tabular}

Table 3. Summary of overall response of the hydrology components of DANSAT to different grid sizes on QN2.

\begin{tabular}{|c|c|c|c|c|c|c|c|c|}
\hline \multirow{3}{*}{$\begin{array}{l}\text { Grid Size } \\
\text { (m) }\end{array}$} & \multicolumn{6}{|c|}{ Surface } & \multicolumn{2}{|c|}{ Subsurface } \\
\hline & \multirow{2}{*}{$\begin{array}{l}\text { Total } \\
\text { Runoff } \\
(\mathrm{mm})\end{array}$} & \multirow{2}{*}{$\begin{array}{l}\text { Ratio } \\
\text { to } 90 \mathrm{~m}\end{array}$} & \multicolumn{2}{|c|}{$\begin{array}{l}\text { Normalized Objective } \\
\text { Function (NOF) }\end{array}$} & \multicolumn{2}{|c|}{$\begin{array}{c}\text { Nash-Sutcliffe Efficiency } \\
\text { Index (NSE) }\end{array}$} & \multirow{2}{*}{$\begin{array}{c}\text { Spatially Averaged } \\
\text { Total Recharge } \\
(\mathrm{mm} / \text { cell })\end{array}$} & \multirow{2}{*}{$\begin{array}{l}\text { Ratio } \\
\text { to } 90 \mathrm{~m}\end{array}$} \\
\hline & & & Monthly & Daily & Monthly & Daily & & \\
\hline 60 & 1795 & 0.99 & 0.13 & 0.36 & 0.69 & 0.52 & 644 & 0.98 \\
\hline 90 & 1812 & 1.00 & 0.13 & 0.36 & 0.68 & 0.52 & 661 & 1.00 \\
\hline 120 & 1849 & 1.02 & 0.13 & 0.38 & 0.68 & 0.44 & 719 & 1.09 \\
\hline
\end{tabular}

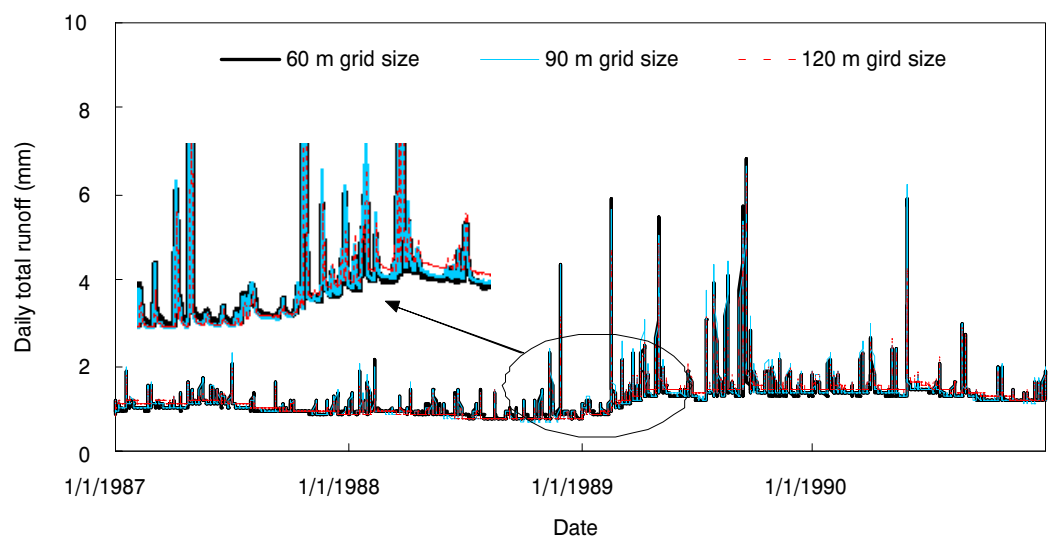

(a)

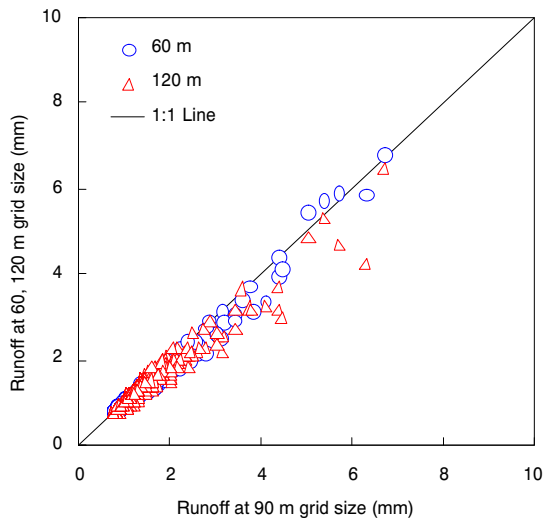

(b)

Figure 4. Comparison of daily total runoff for different grid sizes in the QN2 subwatershed: (a) time series and (b) scatter plot. 


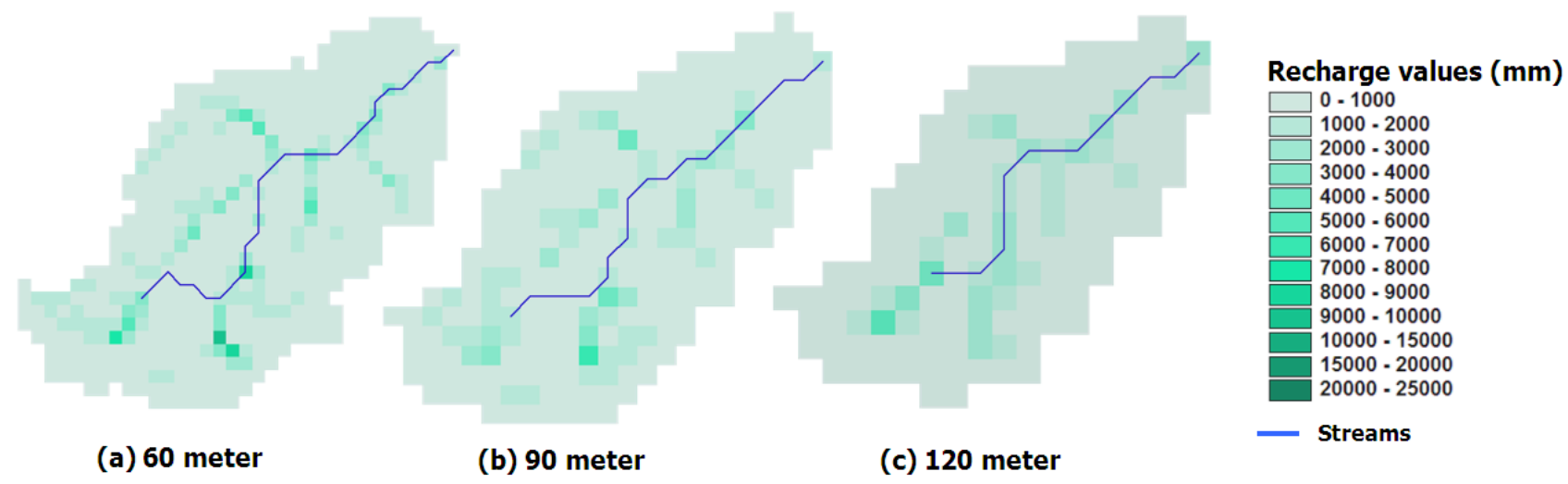

Figure 5. Spatial distribution of groundwater recharge and streams for different grid sizes in QN2.

may be explained by changes in flow path and different sets of soil and land use combinations for the different grid sizes. As mentioned previously, spatial distribution of flow path, soil, and land use can be influenced by changes in grid size. For example, recharge will be higher when a cell exists near a stream where accumulated flow depth is high and the soil is most permeable. In addition, rapid decrease in daily NSE values occurred between the $90 \mathrm{~m}$ and $120 \mathrm{~m}$ grid sizes.

Figure 4 shows a comparison of daily runoff for different grid sizes. Daily runoff values for the $60 \mathrm{~m}$ and $90 \mathrm{~m}$ grid sizes were close to each other, while daily runoff for the $120 \mathrm{~m}$ grid size was smaller than that calculated for the $90 \mathrm{~m}$ grid size (fig. 4b). The fluctuation in baseflow is simulated by the groundwater component of DANSAT using recharge as an input. Baseflow at the $120 \mathrm{~m}$ grid size was higher than at the $60 \mathrm{~m}$ and $90 \mathrm{~m}$ grid sizes (fig. 4a). Daily runoff during large storm events decreased as grid size increased. Both monthly and daily NSE values for runoff were acceptable at the downscaled grid size $(60 \mathrm{~m})$, while only monthly NSE value was acceptable at the up-scaled grid size $(120 \mathrm{~m})$ without any further calibration (table 3).

Spatial distribution of groundwater recharge was analyzed and is presented in figure 5. Baseflow in a stream segment is calculated as a function of the groundwater recharge, saturated hydraulic conductivity, and the straight distance between the upland cell where recharge occurred and the nearest stream cell. The spatial distribution of recharge values can be influenced by variations in the spatial distribution of land use, soil, and topographic parameters due to changes in grid size. Figure 5 shows that cells with a higher groundwater recharge exist near stream networks, where higher accumulated flow depth is available. Maximum recharge value in a cell decreased as grid size increased (fig. 5), while spatially averaged total recharge increased as grid size increased (table 3).

Table 4. Summary of the model response of hydrology components to different time steps considering baseflow component.

\begin{tabular}{|c|c|c|c|c|c|c|c|c|}
\hline \multirow{3}{*}{$\begin{array}{l}\text { Time Step } \\
\quad(\mathrm{min})\end{array}$} & \multicolumn{6}{|c|}{ Surface } & \multicolumn{2}{|c|}{ Subsurface } \\
\hline & \multirow{2}{*}{$\begin{array}{c}\text { Total } \\
\text { Runoff } \\
(\mathrm{mm})\end{array}$} & \multirow{2}{*}{$\begin{array}{l}\text { Ratio } \\
\text { to } 1 \mathrm{~min}\end{array}$} & \multicolumn{2}{|c|}{$\begin{array}{l}\text { Normalized Objective } \\
\text { Function (NOF) }\end{array}$} & \multicolumn{2}{|c|}{$\begin{array}{c}\text { Nash-Sutcliffe Efficiency } \\
\text { Index (NSE) }\end{array}$} & \multirow{2}{*}{$\begin{array}{c}\text { Spatially Averaged } \\
\text { Total Recharge } \\
(\mathrm{mm} / \text { cell })\end{array}$} & \multirow{2}{*}{$\begin{array}{l}\text { Ratio } \\
\text { to } 90 \mathrm{~m}\end{array}$} \\
\hline & & & Monthly & Daily & Monthly & Daily & & \\
\hline 1 & 1812 & 1.00 & 0.13 & 0.36 & 0.68 & 0.52 & 637 & 1.00 \\
\hline 5 & 1880 & 1.04 & 0.14 & 0.36 & 0.63 & 0.50 & 659 & 1.03 \\
\hline 10 & 1910 & 1.05 & 0.16 & 0.37 & 0.54 & 0.49 & 659 & 1.03 \\
\hline 15 & 1923 & 1.06 & 0.17 & 0.37 & 0.50 & 0.47 & 657 & 1.03 \\
\hline 30 & 1937 & 1.07 & 0.18 & 0.39 & 0.44 & 0.42 & 657 & 1.03 \\
\hline 45 & 1945 & 1.07 & 0.18 & 0.40 & 0.42 & 0.39 & 654 & 1.03 \\
\hline 60 & 1949 & 1.08 & 0.18 & 0.40 & 0.41 & 0.39 & 657 & 1.03 \\
\hline
\end{tabular}

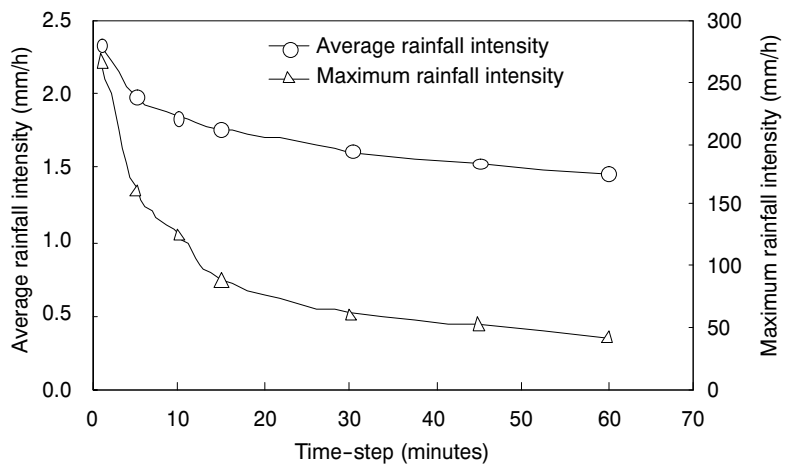

(a)

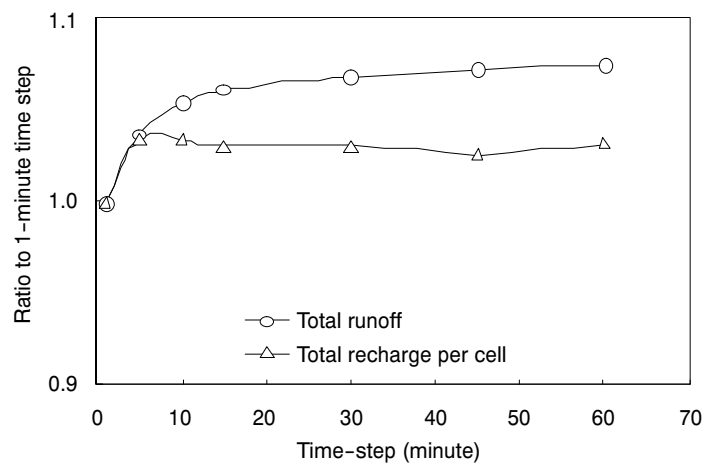

(b)

Figure 6. (a) Average and maximum rainfall intensity and (b) total runoff and spatially averaged total recharges according to different time steps. 


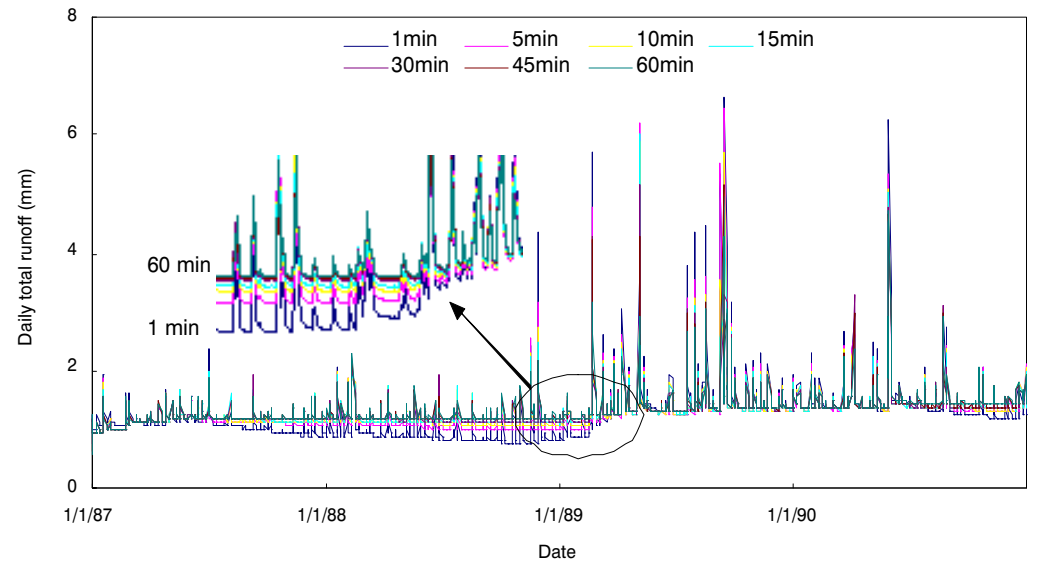

(a)

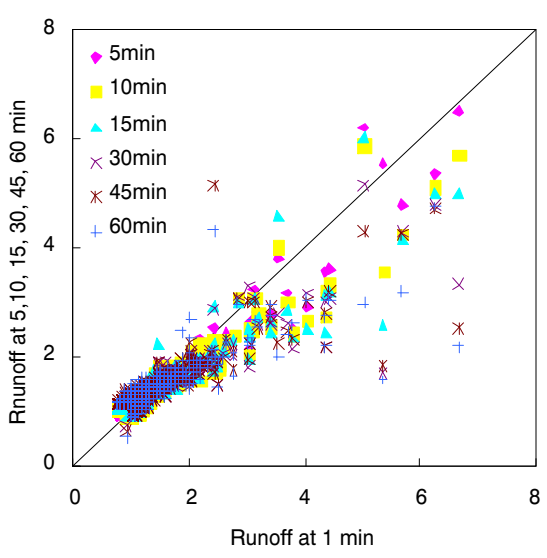

(b)

Figure 7. Time series of daily total runoff for different time steps.

\section{Time Step Sensitivity Analysis}

The response of the hydrology components to different time steps is summarized in table 4 . Total runoff at the watershed outlet increased as the time step increased. An increase in time step from $1 \mathrm{~min}$ to $60 \mathrm{~min}$ increased the total runoff by $8 \%$. The increase in total runoff due to an increase in time step can be explained by the decrease in rainfall intensity, resulting in an increase in recharge value. Figure 6a shows a decrease in both average and maximum rainfall intensity as time step increased. Rapid decrease in rainfall intensities occurred between $1 \mathrm{~min}$ and 5 min time steps. Figure $6 \mathrm{~b}$ shows the response of total runoff and spatially averaged total recharges during simulation period to the changes in time step. It shows rapid increases in total runoff and recharge values between $1 \mathrm{~min}$ and $5 \mathrm{~min}$ time steps, which coincide with the rapid decrease in rainfall intensity shown in figure $6 \mathrm{a}$. Total runoff showed a similar trend to the spatially averaged total recharge. It can be deduced that baseflow components respond more sensitively to an increase in recharge compared to the response of overland components to increased infiltration.

Figure 7 shows the time series and scatter plot of daily total runoff for different time steps. An increase in baseflow and a decrease in streamflow for storm events occurred as the time step increased. The most significant change in both baseflow and streamflow for storm events occurred between the $1 \mathrm{~min}$ and $5 \mathrm{~min}$ time steps (fig. 7a). Changes in total runoff were acceptable, with $8 \%$ of the maximum increase at $60 \mathrm{~min}$, while both the monthly and daily NSE values rapidly decreased as the time step increased. Monthly runoff at time steps greater than $10 \mathrm{~min}$ and daily runoff at time steps greater than 5 min did not satisfy the suggested lower-range NSE value $(0.5)$ for satisfactory model performance (Moriasi et al., 2007) without any further calibration. Both monthly and daily normalized objective functions (NOFs) increased as time step increased. If the main focus of research is to determine long-term hydrologic impacts, then time steps from 1 to $60 \mathrm{~min}$ are acceptable. However, if the research focuses on event-related impacts on hydrology and water quality such as sediment yield, then smaller time steps from 1 to $10 \mathrm{~min}$ will be reasonable considering the widely scattered daily runoff at the high flow depth in figure $7 \mathrm{~b}$. Use of MAG $(90 \mathrm{~m})$ with an acceptable larger time step (10 $\mathrm{min})$ substantially reduced computational time to $6 \mathrm{~min}$, compared to $205 \mathrm{~min}$ at a smaller grid size $(60 \mathrm{~m})$ and time step $(1 \mathrm{~min})$. Site-specific sensitivity analysis is recommended due to the possible differences in response of the hydrology components for watersheds with different hydrologic characteristics.

\section{Summary AND CONClusions}

Structural sensitivity analysis of the hydrology components of DANSAT was conducted to provide a guideline in deciding on an appropriate grid size and time step for reducing computation time. The response of the hydrology components to different grid sizes was analyzed by considering: (1) changes in input parameter values due to GIS manipulation processes (parameter impacts), and (2) overall response of the model due to both parameter impacts and the selected algorithm and equations of the hydrology components (model impacts). The MAG of $90 \mathrm{~m}$ was determined for the QN2 subwatershed based on spatial accuracy of the GIS manipulation processes, such as watershed boundary delineation from DEM and rasterization of soil and land use maps. Overall sensitivity of the hydrology components to both down-scaled $(60 \mathrm{~m})$ and up-scaled $(120 \mathrm{~m})$ grid sizes was analyzed in the QN2 subwatershed, where baseflow is the dominant flow. Total runoff at the watershed outlet increased with larger grid sizes. The increase in grid size influenced the spatial distribution of recharge and resulted in an increase in baseflow and total runoff. Only the overall response of the hydrology components to the down-scaled $(60 \mathrm{~m})$ grid sizes was acceptable without any further calibration.

Sensitivity analysis of the hydrology components to different time steps was conducted on the QN2 subwatershed by changing the storm event time step from $1 \mathrm{~min}$ to $60 \mathrm{~min}$ at a fixed grid size $(90 \mathrm{~m})$. The increase in time step influenced the temporal variation of rainfall intensity, which caused increases in infiltration and recharge. Daily streamflow for storm events decreased, while total runoff was stable with a slight increase $(8 \%)$ as the time step increased from 1 to $60 \mathrm{~min}$. Total runoff at the watershed outlet increased as the time step increased, with a combined influence of increase in baseflow and decrease in streamflow for storm events. Use of the MAG $(90 \mathrm{~m})$ with an acceptable larger time step (10 $\mathrm{min})$ substantially reduced computational time, compared to an 
application using the smaller grid size $(60 \mathrm{~m})$ and time step (1 min). Stable response of the hydrology components to specific ranges of grid size and time step showed that the user can select a larger grid size or time step with minimum calibration. Increased grid size or time step dramatically decreased computational time; this information will be very helpful for practical model application. However, it should be noted that a site-specific structural sensitivity analysis at different watersheds is recommended due to the different hydrologic characteristics and responses of different watersheds.

\section{REFERENCES}

Armstrong, R. N., and L. W. Martz. 2003. Topographic parameterization in continental hydrology: A study in scale. Hydrol. Proc. 17(18): 3763-3781.

Arnold, J. G., R. Srinivasan, R. S. Muttiah, and J. R. Williams. 1998. Large-area hydrologic modeling and assessment: Part I. Model development. JAWRA 34(1): 73-89.

Bicknell, B. R., J. C. Imhoff, J. L. Kittle, Jr., A. S. Donigian, Jr., and R. C. Johanson. 1993. Hydrologic Simulation Program-FORTRAN (HSPF): User's Manual for Release 10. Report No. EPA/600/ R-93/174. Athens, Ga.: U.S. EPA Environmental Research Laboratory.

Bingner, R. L., and F. D. Theurer. 2001. Topographic factors for RUSLE in the continuous-simulation watershed model for predicting agricultural, nonpoint-source pollutants (AnnAGNPS). In Proc. Intl. Symp.: Soil Erosion Research for the 21st Century, 619-622. St. Joseph, Mich.: ASABE.

Borah, D. K., and M. Bera. 2003. Watershed-scale hydrologic and nonpoint-source pollution models: Review of mathematical bases. Trans. ASAE 46(6): 1553-1566.

Borg, H., and D. W. Grimes. 1986. Depth development of roots with time: An empirical description. Trans. ASAE 29(1): 194-197.

Bouraoui, F., and T. A. Dillaha. 1996. ANSWERS-2000: Runoff and sediment transport model. J. Environ. Eng. 122(6): 493-502.

Brasington, J., and K. Richards. 1998. Interactions between model predictions, parameters, and DTM scales for TOPMODEL. Computers and Geosci. 24(4): 299-314.

Brown, D. G., L. Bian, and S. J. Walsh. 1993. Response of a disturbed watershed erosion model to variations in input data aggregation levels. Computers and Geosci. 19(4): 499-509.

Campbell, J. B. 2002. Introduction to Remote Sensing. Boca Raton, Fla.: CRC Press.

Cho, J. 2007. A comprehensive modeling approach for BMP impact assessment considering surface and groundwater interaction. $\mathrm{PhD}$ diss. Blacksburg, Va.: Virginia Polytechnic Institute and State University.

Cho, J., and S. Mostaghimi. 2009a. Dynamic Agricultural Nonpoint Source Assessment Tool (DANSAT): Model application. Biosystems Eng. 102(4): 500-515.

Cho, J., and S. Mostaghimi. 2009b. Dynamic Agricultural Nonpoint Source Assessment Tool (DANSAT): Model Development. Biosystems Eng. 102(4): 486-499.

Cho, J., and S. Mostaghimi. 2009c. Evaluating cell-based components of DANSAT for predicting surface and subsurface transport of pesticides. Biosystems Eng. 102(4): 473-485.

Chu, S. T. 1978. Infiltration during an unsteady rain. Water Resour. Res. 14(3): 461-466.

Dillaha, T. A. 1990. Role of best management practices in restoring the health of the Chesapeake Bay. In Perspectives on the Chesapeake Bay, 1990: Advances in Estuarine Sciences. CBP/TRS41/90. Washington, D.C.: USEPA, Chesapeake Bay Program.

ESRI. 1998. ArcView GIS, Version 3.1. Redlands, Cal.: Environmental Systems Research Systems, Inc.

Green, W. H., and G. Ampt. 1911. Studies of soil physics: Part I. The flow of air and water through soils. J. Agric. Sci. 4: 1-24.
Inamdar, S. P., S. Mostaghimi, P. W. McClellan, and K. M. Brannan. 2001. BMP impacts on sediment and nutrient yields from an agricultural watershed in the Coastal Plain region. Trans. ASAE 44(5): 1191-1200.

Kuo, W.-L., K., T. S. Steenhuis, C. E. McCulloch, C. L. Mohler, D. A. Weinstein, S. D. DeGloria, and D. P. Swaney. 1999. Effect of grid size on runoff and soil moisture for a variable-source-area hydrology model. Water Resour. Res. 35(11): 3419-3428.

Moglen, G. E., and G. L. Hartman. 2001. Resolution effects on hydrologic modeling parameters and peak discharge. J. Hydraulic Eng. 6(6): 490-497.

Molnar, D. K., and P. Y. Julien. 2000. Grid-size effects on surface runoff modeling. J. Hydrol. Eng. 5(1): 8-16.

Moriasi, D. N., J. G. Arnold, M. W. Van Liew, R. L. Bingner, R. D. Harmel, and T. L. Veith. 2007. Model evaluation guidelines for systematic quantification of accuracy in watershed simulations. Trans. ASABE 50(3): 885-900.

Mostaghimi, S., U. S. Tim, P. W. McClellan, J. C. Carr, R. K. Byler, T. A. Dillaha, V. O. Shanoltz, and J. R. Pratt. 1989. Watershed/water quality monitoring for evaluating BMP effectiveness: Nomini Creek watershed. Pre-BMP evaluation. Final Report N-P1-8906. Richmond, Va.: Virginia Department of Conservation and Historic Resources, Division of Soil and Water Conservation.

Nash, J. E., and J. V. Sutcliffe. 1970. River flow forecasting through conceptual models: Part 1. A discussion of principles. J. Hydrol. 10(3): 282-292.

Neitsch, S. L., J. G. Arnold, J. R. Kiniry, and J. R. Williams. 2002. Soil and Water Assessment Tool Theoretical Documentation Version 2000. GSWRL Report 02-01. Temple, Tex.: USDA-ARS Grassland Soil and Water Research Laboratory.

Panuska, J. C., I. D. Moore, and L. A. Kramer. 1991. Terrain analysis: Integration into the agricultural nonpoint-source (AGNPS) pollution model. J. Soil Water Cons. 46(1): 59-64.

Priestley, C. H. B., and R. J. Taylor. 1972. On the assessment of surface heat flux and evaporation using large-scale parameters. Monthly Weather Review 100(2): 81-92.

Refsgaard, J. C. 1997. Parameterisation, calibration, and validation of distributed hydrological models. J. Hydrol. 198(1/4): 69-97.

Ritchie, J. T. 1972. Model for predicting evaporation from a row crop with incomplete cover. Water Resour. Res. 8(5): 1204-1213.

Saulnier, G. M., K. Beven, and C. Obled. 1997. Digital elevation analysis for distributed hydrological modeling: Reducing scale dependence in effective hydraulic conductivity values. Water Resour. Res. 33(9): 2097-2101.

Savabi, M. R., and J. R. Williams. 1995. Chapter 5: Water balance and percolation. In WEPP Technical Documentation. NSERL Report No. 10. D. C. Flanagan and M. A. Nearing, eds. West Lafayette, Ind.: USDA-ARS National Soil Erosion Research Laboratory.

Sloan, P. G., I. D. Morre, G. B. Coltharp, and J. D. Eigel. 1983. Modeling surface and subsurface stormflow on steeply sloping forested watersheds. Report 142. Lexington, Ky.: University of Kentucky, Water Resources Research Institute.

Valeo, C., and S. M. A. Moin. 2000. Grid-resolution effects on a model for integrating urban and rural areas. Hydrol. Proc. 14(14): $2505-2525$

Vazquez, R. F., L. Feyen, J. Feyen, and J. C. Refsgaard. 2002. Effect of grid size on effective parameters and model performance of the MIKE-SHE code. Hydrol. Proc. 16(2): 355-372.

Vieux, B. E., and S. Needham. 1993. Nonpoint-pollution model sensitivity to grid-cell size. J. Water Resources Planning and Mgmt. 119(2): 141-157.

Williams, J. R. 1969. Flood routing with variable travel time or variable storage coefficient. Trans. ASAE 12(1): 100-103.

Xevi, E., K. Christiaens, A. Espino, W. Sewnandan, D. Mallants, H. Sorensen, and J. Feyen. 1997. Calibration, validation, and sensitivity analysis of the MIKE-SHE model using the Neuenkirchen catchment as case study. Water Resources Mgmt. 11(3): 219-242. 